\title{
Is Service Design in Demand?
}

\author{
by Qian Sun and Carolyn Runcie
}

This article reports on an empirical study that investigates the work experience of graduates from a service design program in a leading art and design institution. Drawing on the findings from reviewing 30 online profiles of the graduates and interviewing 12 of them, this article explores the challenges and opportunities for service design as a profession in relation to the current demand in private-, public-, and third-sector organizations. The article concludes that the scope and integrity of service design within organizations depends on the organizational contexts, for example, how service design is perceived and how open the organization is to new ways of working; therefore, it could be said that it is potentially compromised by a lack of frameworks that underpin service design practice. In many ways, service design has become a responsive reformulation of practices from different fields. Although the demand for the service design graduates from this program is high, the continuous development of service design depends on the extent of success of the experiments and implementation achieved by its early adopters.

Key words: service design, design education, design management

\section{The context: the emergence of service design}

Recent years have witnessed an imperative for organizations from the private, public, and third sectors to innovate in the growing service economy. In this context, service design has emerged and is considered a tool to deliver innovative customer experiences in businesses as well as to transform the quality and value of public- and third-sector services. For the design communities, many believe that service design is the frontier of design practice, assuming a considerable role in the increasingly dominant service economy. In the literature, the key areas where service design is considered valuable include designing for service innovation (e.g., Rodriguez and Peralta, 2013; Sangiorgi, Prendiville, Jung, and Yu, 2015), designing the public sector (e.g., Armstrong, Bailey, Julier, and Kimbell, 2015; Bason, 2014; Design Commission, 2014b), and design for social innovation (e.g., Burns, Cottam, Vanstone, and Winhall, 2006; Manzini, 2011; Manzini and Staszowski, 2013). There is a shared trend in all these areas of innovation that calls for a more distributed and collaborative approach. This leads to the exploration of alternative methods and ways of working. Based on this proposition, the literature has attempted to rationalize the role of service design in all these areas. 


\section{The relevance of service design}

With the continuously growing service economy, it is believed important to shift from a firm-centric way of doing business toward an approach that puts consumer experiences at the center (Prahalad and Ramaswamy, 2004). Thus, a majority of businesses are making the critical shift from product-centric to service-centric thinking (Gruhl, Bailey, Spohrer, and Maglio, 2007; Spohrer and Maglio, 2010; Vargo and Lusch, 2011). Just as IBM has moved from selling smarter computers to delivering the product-service systems that could make cities smarter, Rolls-Royce has transformed its business model to offer engines as a service, literally selling thrust or power by the hour and retaining asset and maintenance services; design is therefore considered by Leon and Davies (2008) to be valuable in this transformation in that it configures the provision of services to create the added value that delivers longer-term customer relationships and larger profit margins.

The public sector is struggling with how to balance increasing demand with diminishing resources (Manzini and Coad, 2015; Manzini and Staszowski, 2013; Mulgan, 2014a, 2014b). Mulgan, Tucker, Ali, and Sanders (2011) believe that over the next 20 years, the biggest challenges in Organisation for Economic Co-Operation and Development countries are likely to be in health, education, and care, and the rising demand for these services has exerted pressure on political leaders for new solutions. More and more governments seek alternative approaches to policy implementation that promise to innovate and transform public services. Through pioneering a range of projects exploring the role of design in public service innovation, Burns et al. (2006) suggest that designers are uniquely placed to help solve complex social issues, leading to changes in the way public services are delivered.

Similarly, in policy making, the importance of the distribution of power and the role of interest groups in the decision-making and policy process has been recognized (Brugha and Varvasovszky, 2000). As such, democratization, rising literacy, the advent of the information age, and increasing connectedness are resulting in unprecedented opportunities for public participation in public affairs (Alderman, Hipgrave, and Jimenez- Soto, 2013). This leads to the promotion of transparency, demonstrating inclusiveness, enhanced ownership, and decentralization of public services. Under this context, Bason (2014) suggests that design may offer a fundamental reinvention of the art and craft of policy making in the 21 st century. He considers that "from challenging current problem spaces to driving the creative quest for new solutions and shaping the physical and virtual artefacts of policy implementation, design holds a significant yet largely unexplored potential” (p. 3).

In a social economy, the rise of distributed networks has changed the perceived role of individuals from 
passive to active players in many social and economic settings. Much of Manzini's work (e.g., Manzini and Staszowski, 2013) has focused on promoting design for social innovation, considering that design experts can trigger and support meaningful social changes; thus, focusing on emerging forms of collaboration becomes important.

\section{The development of service design communities}

The imperative for service innovation has led to the development of service design as a profession. Since the establishment of the Service Design Network (SDN) 30 years ago (aiming to develop and establish the discipline and professional identity of service design internationally, through its Touchpoint journal, the Case Study Library, and an annual global conference dedicated to Service Design), service design has developed into a more established profession. In the United Kingdom, a number of well-known consultancies, including Livework, Engine, and IDEO, practice service design, serving a wide range of clients from the private, public, and third sectors, including the BBC, Transport for London, Barclays, VW, Vodafone, Virgin, Jaguar, and Philips. Service design also increasingly draws interest from the public sector. There are ample publications elaborating on the practice of service design. For example, This Is Service Design Thinking (Stickdom, Schneider, and Marc, 2014) combines contributions from the service design community that outline the basic principles of service design thinking, tools, and cases. Other publications include the recent work of Pinheiro (2014), which explores how startup entrepreneurs and business leaders can integrate service design into their fast-paced development cycles; and Newbery and Farnham (2013) teach businesses how to think about design as a process and how this process can be used to create a better quality of experience across the entire customer journey. These publications all focus on tools, methods, processes, and case studies in service design.

\section{Theoretical development of service design}

Although the service design community itself explores the boundaries of service design as a profession, as a new academic discipline, service design is also defining its theoretical relevance (Kimbell, 2011; Madano Partnership, 2012; Sangiorgi, Prendiville, and Ricketts, 2014). As the Madano Partnership (2012) suggests, "The definition and boundaries of service design as a discipline are contested in both academia and professional practice, presenting significant opportunity for further research and exploration" (p. 1).

One of the earlier attempts in theoretically defining service design is by Sangiorgi (2008), who takes a 
social network perspective and considers services as "the result of direct and indirect encounters among people belonging to different Activity Systems, with different perspectives, practices and goals"; thus, service design has become the design of the material (products, information, and environments) and social (rules and roles) conditions that facilitate and enable certain kinds of actions and behaviors. Her later work (2010) suggests that, because services are increasingly considered as an engine for wider societal transformations, the value of service design lies in its ability to work across organizations and communities to enhance transformational processes. Secomandi and Snelders (2011) take a different approach to the definition of service design. Instead of developing more elaborate analyses of the design of service infrastructures and systems, they suggest that the client-provider interface is crucial. Focusing on developing the understanding of service design, Kimbell's (2011) framework presents key tensions between the understandings of design (either as problem solving or as an exploratory inquiry) and service (as distinct from goods or as a fundamental activity of value constellation).

These different perspectives indicate that service design is developing toward a multidisciplinary subject. Most research aiming for theoretical development in this field has introduced a range of bodies of knowledge and discussed their relevance to service design. This includes, for example, social networks (Sangiorgi, 2008), service science (Kimbell, 2009), organizational change (Junginger and Sangiorgi, 2009), systemic design (Jones, 2014), service innovation (Tether, 2013), and the experience economy (Zomerdijk and Voss, 2010).

However, based on the results of a range of research workshops, Sangiorgi et al. (2014) suggest that service design as a discipline is not defined and there is a need for more research exploring its definition, core practice, and borders. These include a need for discussions on the object and extended design spaces of service design; the need to shift attention to more contextualized research and argument around the value and limitations of service design and for the development of more effective dialogue and collaboration across disciplines and sectors; and the need to connect service design with digital innovation, social innovation, social change, or policy making, opening up novel realms of investigation and raising questions that need our attention.

\section{The focus}

Much of the discussion about the relevance of service design has not gone far beyond an exploratory stage in research. There is little empirical research to evidence the extent to which the interests have been translated into sustained demand from the wider stakeholder communities, namely, businesses, the public 
and third sectors, and government. More importantly, there is a need to understand the status of service design as a profession in relation to the potential demand. This is challenged by the fact that service design, as an academic discipline, is not defined. Effectively, there are two strands of knowledge about service design. One is mainly based on informal and tacit knowledge from practice (Kimbell, 2011), as found in the case studies developed majorly by design practitioners, such as those found in SDN's Case Study Library. Most of these case studies do not aim to advance the theoretical thinking in service design but rather to share best practice within the service design communities and promote service design to potential clients and the general public. Service design academics, instead, focus on the theoretical development of the discipline through bridging dialogues across disciplines. However, there is a lack of a contextualized understanding and argument around the value and limitations of service design in practice.

This study, taking a different angle, aims to contribute to the discussion in attempting to understand the status of service design as a profession. It investigates the work experience of recent service design graduates. This is based on the phenomenon that higher education institutions (HEIs) have recently joined the force of service design, evidenced by the proliferation of service design programs in recent years. These include the Master's in Service Design at the Royal College of Art (RCA), MDes Service Design Innovation at the University of the Arts London, Design Innovation and Service Design at Glasgow School of Art, Service Design at Savannah College of Art \& Design, Service Design at Politecnico di Milano, Service Design and Engineering at Aalto University, and the Social Innovation Program at Parsons School of Design, New York.

These service design programs undoubtedly play a crucial role in developing service design as a profession as well as a discipline. Since the shift from a dominant industry-government dyad in the Industrial Society to a growing triadic relationship between university, industry, and government in the Knowledge Society, HEIs play a more prominent role in innovation and economic development (Triple Helix Research Group, 2010). Thus, it is expected that the content of the curricula and their involvement in wider communities contribute to the understanding of the current state of service design. The work experience of their graduates exclusively implies the nature of demand for the service design profession, informing the theoretical understanding of the subject. This presents a significant, although neglected, research topic. Based on this proposition, this study aims to identify the potential challenges for service design as a profession in relation to current demand.

\section{The approach}


Among these new programs, the Master's in Service Design program at the RCA is uniquely positioned due to its historical influence over the design communities and wider industry. Therefore, it presents a critical case study. As Yin (2011) suggests, a critical case study leads to building a formidable theory with a set of propositions and to producing knowledge contributions. Suggested by Donmoyer (2000), this approach has more utility for applied fields. Although it is recognized that this approach is limited by the generalizability of data, it is appropriate to achieve the aim of the study, which is to identify propositions and emerging issues in service design.

The Master's in Service Design at the RCA was launched in 2012 as a contingent outcome of Design London (2007-2011), a research project between Imperial College and the RCA, with the aim to develop, research, and disseminate new practices, tools, and processes to enhance innovation in the private, public, and third sectors. Developed from the Design London platform, the Master's in Service Design program is fully embedded and connected with both the design, technology, and business communities and wider industry. It is a two-year master's program with a total of 70 students registered when the data were collected. The students are from a wide range of backgrounds, with 60 percent of them being international students. It claims to be the largest postgraduate program dedicated to service design. It has since graduated two cohorts of 36 students in total. The program is one of the pioneering courses to test the concept of service design as a profession as well as an academic discipline. The program was selected as a case study due to its influence within the design community and connections with industry.

The case study has been developed using both qualitative and quantitative data. First, the profiles of 30 graduates (from the 2012/14 and 2013/15 cohorts with a total of 36 graduates) were reviewed, based on information drawn from LinkedIn profiles that are updated and made available to the public. Following this, 12 alumni were selected for interview based on their availability, through e-mails, social media, and Skype calls. In the interviews, a total of 16 questions were asked, relating to their current roles, organizations they work for, projects, and their views toward service design.

\section{The findings}

\section{Employment sectors}

Reviewing the online profiles of 30 alumni reveals that these graduates work in different sectors, as shown in Figure 1. 


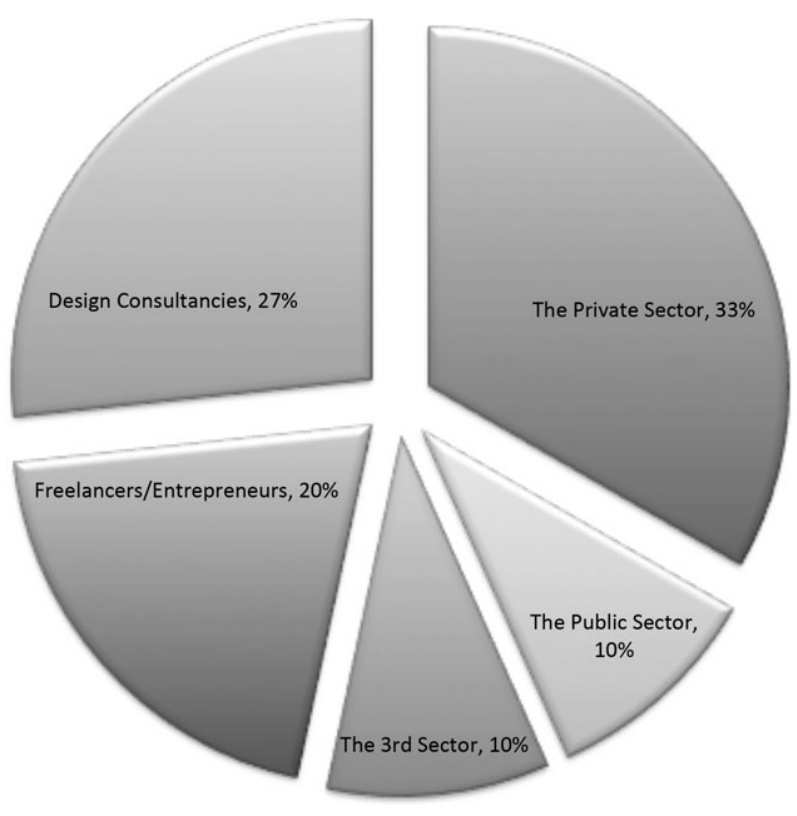

Figure 1. Employment of alumni.

The highest percentage of students work for private-sector organizations, the majority of which are big corporations and multinationals, including IBM, Samsung, Royal Bank of Scotland, Hyundai, Barclays, and Tesco. Design consultancies are the second highest destination. These include leading design consultancies such as Fjord, Engine, and IDEO. Twenty percent are freelancers or entrepreneurs. In comparison with a recent report (Public and Corporate Economic Consultants, 2015), which suggests that art and design-related subjects in particular lead to enterprise pathways (in over half of startups/spinouts), the figure of 20 percent in this case is significantly lower.

The public and third sectors have recruited relatively few graduates from this program. However, in reviewing the projects of those working as freelancers and for design consultancies, there is a high level of involvement with the public and third sectors. It may imply that these organizations tend to outsource service design capabilities to meet the demand for this evolving approach. It is also noticeable that there is a significant overlap between the organizations that hire graduates from the program and the ones that collaborate with the program either through sponsoring projects or giving talks or tutorials to students.

\section{Job titles and career paths}

Drawn from data from the online profiles, the job titles of these graduates can be grouped into four categories, as shown in Figure 2. Thirty three percent of the graduates work as service designers and 
designers, whereas others work in the fields closely linked to service design, such as interaction design, UX design, and experience design. Thirty seven percent of the graduates are involved in project and strategic management duties, as team leaders, founders, and managers. Interestingly, 10 percent specifically work in the field of design research or user research. This is different from a research role in academia and focuses on providing inputs based on insights that reflect an understanding of user needs to identify design opportunities.

Profiles also show that a considerable number of graduates have had more than one job during the limited years since graduating (1-3 years). A few have more than one job at the same time. This is consistent with the career path characteristics of designers identified in Sun's (2011) research, which considers that the career of design students is featured as "portfolio based," with complex career paths and high transfer rates to other disciplines. Different from what is reported in Sun's (2011) research, most graduates from this program entered the job market before or shortly after graduation.

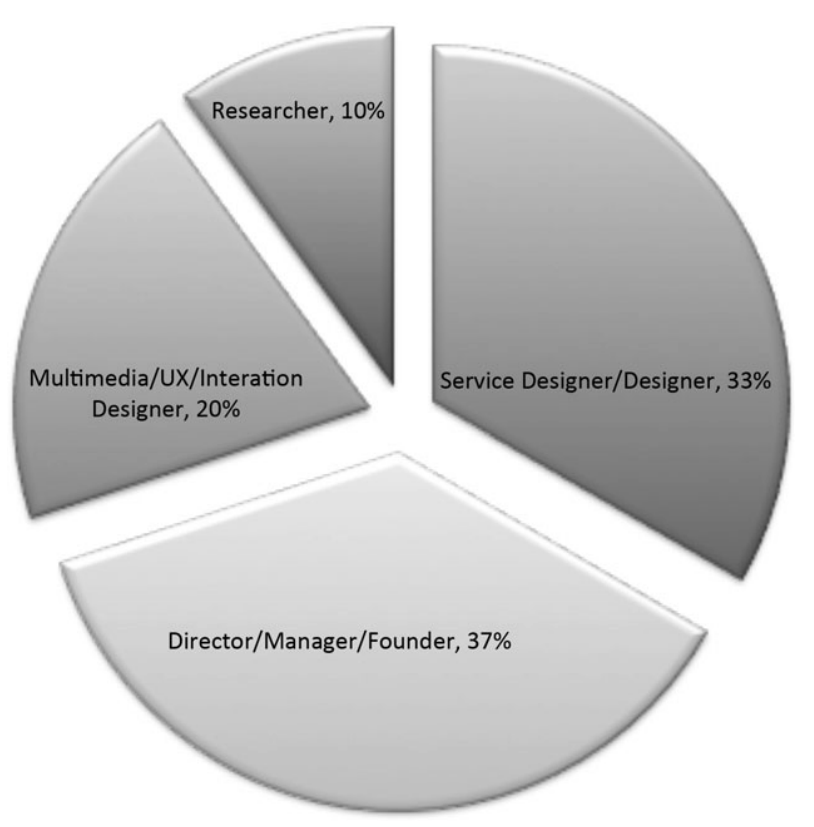

Figure 2. Job titles.

\section{Tasks and roles in jobs}

In the interviews, questions were asked regarding the roles and tasks of jobs. It appears that many of them have to fulfill a range of versatile roles and tasks. Four distinctive areas are identified as being important across the interviews. Project management and leadership appear at the top of the list of responsibilities 
and include skills such as liaising with clients, coaching service design methodologies, coordinating team efforts, project management, managing budgets, accountancy, to enable and empower, administration, team building, business development, and strategies.

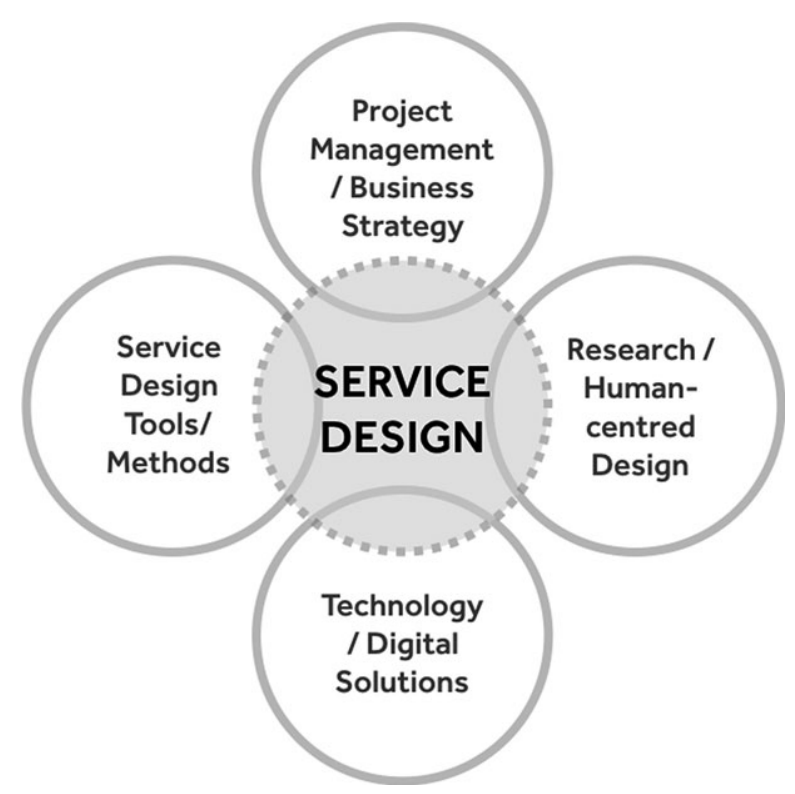

Figure 3. Tasks and roles in jobs

The second area reflects the process of service design, which involves planning and running workshops (co- creation and co-design), developing user personas and journey maps, synthesizing insights, concept development and validation, prototyping, visualizing service models, and creating reports that capture process and vision for relevant stakeholders. The third area involves providing digital solutions.

Therefore, terms such as interaction design, digital experience, Web design, HTML5 \& CSS3, UI \& UX, and social media support were used. Research was another word frequently used to describe tasks. It is separated from the process of service design because the research outcomes were the deliverables of the tasks in many cases. The concept of human-centered design was placed in the center of the research tasks. Figure 3 summarizes these findings, showing that, apart from the defined service design activities, there are three key areas that are potentially important to service design professionals: project management, providing information technology (IT) solutions, and research.

\section{Qualities and knowledge}

The qualities, skills, and knowledge that are important in these cases include those related to professional 
development, such as the ability to collaborate, working under pressure, dealing with uncertainty, independency, ability to learn, listening skills, leadership, public speaking, humility, and self-motivation. Interestingly, the skills, qualities, and knowledge that are emphasized heavily in most art and design schools, such as creativity and imagination, were not mentioned.

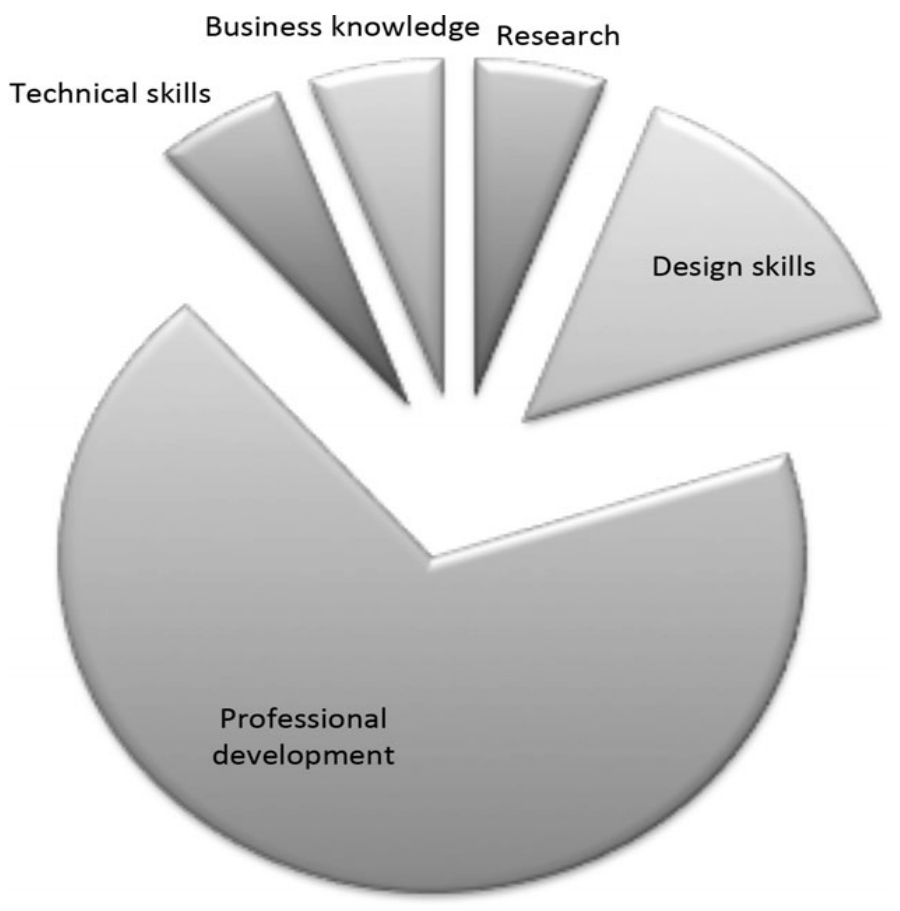

Figure 4. Qualities and knowledge.

\section{Challenges}

When asked about the challenges faced in their jobs, some of the interviewees mentioned the struggle to position themselves professionally in the organization, due to a low awareness of service design practice. For example, they reported that:

Stakeholders of the project challenge every single step made when introduced to new design methods and skills. I have to convince them at every moment such as the purpose of a co-creation workshop and field-work...

It is still hard to explain what service design is, where a service designer's strengths lie. I have always found the proof is in the doing, but you have to get people to trust you in order to get that far...

Therefore, getting the right level of support from an organization can be challenging. For example: 
Helping clients take up service design thinking. It's difficult to shift a mindset when corporations already have a way of thinking and doing things. It's almost like converting someone to a whole new religion. It takes time, patience and perseverance to really help people embody the religion of design.

The organisation needs to be very involved in order to get buy-in from the beginning, but more importantly guarantee that the current reality of the organisation is taken into account as the starting point of any intervention.

This has led to the fact that some graduates have had to spend considerable time working out their role within an organization or change their career paths. This may also be one of the reasons why only 33 percent of the graduates (of the 30 graduates whose profiles were reviewed in this study) have the job title "service designer." This may also explain why professional development skills, in comparison with subject knowledge and technical skills, are considered more important, as discussed above.

This also relates to another challenge service design graduates face in pursuing the discipline they were trained in: Some of them feel that they have to constantly learn, especially knowledge of the industries within which organizations operate, for example, healthcare, housing, and IT:

...(to learn) various fields of knowledge and experience, because it's really hard to expect what knowledge is useful as a service designer when working in different domains...

We also have to switch our thinking very often and rapidly from being experts on ... to...

These challenges indicate that service design is an applied subject and is largely determined by the context in which it is being applied. This also influences how they perceive service design since graduating.

\section{Perspectives on service design}

In attempting to champion service design and to learn consistently, graduates' views toward service design have evolved. They generally consider service design and design thinking as being valuable in their workplaces. Some consider that "service design is the future of the design discipline." A majority of them describe service design as a philosophy, a way of thinking, an overall approach, or a process. Therefore, its usefulness/relevance depends on how it is applied. Some strongly emphasize the importance of collaboration with other disciplines, as "service design can achieve absolutely nothing on its own." It is also realized by the majority of them that the ambition of a designer to "make a change" in a service is 
largely constrained by reality. For example:

The complexity of services makes it difficult to "fix" problems. Actually there is no easy way to "fix" an issue and a complete rejection of the current system is a mistake, while starting from the beginning is not an option.

There are also divided views toward UX/UI in relation to service design. Some consider that "the idea of service design is kind of embedded and diluted into the general idea of UX," whereas others think that service design is ill perceived. For example, one respondent stated, "They told me that they need better designed User Experience. Whereas what is really required is a good service not purely good User Experience design." And another stated, "Technology is overrated and relationships are underrated."

It is a shared view that the current framework underpinning service design practice does not naturally lead to the implementation or delivery of service ideas; therefore, it is unclear what real impact service design could have. For example, a respondent stated, "Service Design is not good at implementing or delivering." Other responses included:

In my opinion, Service Design is one layer of probably the strongest framework to deliver innovative solutions. This framework has two more layers: Agile Methodologies and Lean Thinking. Nowadays, this framework also relies on data and technology to deliver real impact.

I would like to learn more about how exactly to implement a pilot with a real organisation.

\section{Discussion}

\section{The diversity of demand}

The result shows that the demand for service design graduates from this program is considerable. Although only a third of the investigated graduates hold a job title as "service designer," nearly all of them work in an area that is part of the growing service economy, no matter whether they are managing a design team, developing a new enterprise, or implementing new services. This might imply that the growing service economy has to some extent changed the demand for design. Statistics show that economies in both developed and developing countries are increasingly dominated by services. For example, 79 percent of UK gross value added is accounted for by the services sector (Office for National Statistics, 2016) and for the first time, services overtook manufacturing as China's biggest employer in 2011 (Yao, 2014). Gronroos (2007) suggests that when considering the hidden services from manufacturing and agriculture, the scale is significantly larger than what the statistics indicate. This means 
that services in their different forms and characteristics have developed a fundamental role in the economy. This presents significant opportunities for design to push its boundaries and play a role in this increasingly important area.

Given the diversity of the service economy, the demands are not constricted to one single sector, but spread over a wide range of areas, including health, IT, education, and housing. It appears that multinational corporations are major employers for service design graduates.

Interestingly, public-sector organizations that have hired service design graduates are all UK governmental departments. In the United Kingdom, there is a growing interest in designing for policy and public services, as promoted by trade associations and governmental organizations (e.g., Design Commission, 2014a). There is an expectation to normalize design practice in the public sector. Given that 43.2 percent of UK gross domestic product in 2015 was spent by the government (Trading Economics, 2016), this represents a significant area for service design. In many ways, the uptake of service design graduates in these governmental departments reflects the trend. However, this does not seem equally shared by other countries and regions, for example, the United States and Korea. In those countries, none of the service design graduates have taken up positions in the public sector, and most seem to be more engaged in UX/UI design or design related to business strategy. Although this cannot be generalized due to the nature of the data used, the diversity of demands indicates a significant challenge in defining the profession of service design. On another level, the clients' awareness and understanding of the profession plays an important role in the negotiation of the space for service design. The fact that some of the graduates have had to clarify their roles within an organization at the start of the job reflects that not all organizations taking up service design graduates fully understand or share the same views as these graduates. It may well be that some organizations take the risk of trying it out for its promoted promise. As such, many of the interviewees felt that the challenges reside in convincing and educating the clients or the organizations they work for.

Service design is undeligfiligned. The challenge is to some extent attributed to the fact that service design as a discipline is not yet well defined. This may have limited the wider adoption of service design in organizations. In both questions regarding roles and essential skills, there are significant variations depending on the contexts where service design is practiced. As an applied practice, service design appears to be intention based or issue based. Therefore, depending on the nature of issues and intentions, the relevance of the methods and skills varies significantly. The majority of the interviewees felt that skills and methods required in a particular industry that are outside service design methods are important, for example, project management, research, and technological skills (as shown in Figure 1); and the 
qualities important to the roles are more related to personal development (as shown in Figure 4), for example, being a constant learner. This in turn creates challenges in developing a consistent disciplinary framework for service design, as most service design research aims to do. This is especially a challenge when a consistent disciplinary framework is important in order to understand and facilitate collaborative work (which is essential to service design; Dykes, Rodgers, and Smyth, 2009). It is subsequently challenging to identify the core methods underpinned by a knowledge structure. In many ways, service design has become a responsive reformulation of practices, as such demonstrating its undisciplinarity (Marshall and Bleecker, 2010), "an ability to mash together jumbled ideas and methods from a number of different, distinct disciplinary practices that can be brought together to create new unexpected ways of working and new projects" (Bremner and Rodgers, 2013).

\section{Is service design in demand?}

This leads to the question of whether the high level of student career prosperity from this program is shared across all service design programs, due to the fact that the data are limited in generalizability. Is service design in demand on a scale that allows a new discipline to be developed to an advanced level? There are numerous success stories and case studies to show the value of service design, as promoted by the trade associations and the design community (e.g., Design Commission, 2014a). These have resulted in the growth of interests and expectations, and some early adopters are willing to experiment with service design as an alternative solution, such as the organizations buying into service design in this case study. However, for a majority of organizations, service design is a new concept. It appears that even the organizations trying service design hold diverse views toward it. As a result, the graduates find it challenging to establish the integrity of service design within an organization. On the other side, service design certainly has not yet crystalized its offering, being context dependent. There is therefore a question as to whether service design can continue to grow when the inflated expectations fade should experiments and implementations fail to deliver; in the interviews, implementation and delivery were raised as barriers to the success of service design.

\section{Conclusion}

The findings suggest that the wider adoption of service design is challenged by a range of issues. First, the role of service design in the service economy is undefined, although the growing service economy 
presents significant opportunities. Clients' awareness and understanding of the profession plays an important role in the negotiation of the space for service design in industry. There are noticeable variations across regions in terms of the nature of demand for the service design profession. In particular, design for policy and the public sector seem to be UK specific, perhaps due to the promotion and a high awareness of service design in this sector, although design for experience and design for technology solutions are more relevant to countries like Korea and the United States. Consequently, the diversity of demands indicates a significant challenge in defining the profession of service design in return. In many ways, service design has become a responsive reformulation of practices, as such demonstrating its undisciplinarity. However, it is recognized that the data are limited in generalizability because of the RCA's unique position in art and design education. Further studies are needed to develop a better understanding of the status of service design in relation to the demand from industry. This is also a significant question for design management, given the dramatically growing interests in this emerging practice: service design.

\section{References}

Alderman, K. B., Hipgrave, D., Jimenez-Soto, E. (2013). "Public Engagement in Health Priority Setting in Low- and Middle-Income Countries: Current Trends and Considerations for Policy." PLoS Medicine, 10(8), e1001495.

Armstrong, L., Bailey, J., Julier, G., Kimbell, L. (2015). Social Design Futures: HEI Research and the AHRC. Brighton, UK: University of Brighton.

Bason, M. C. (2014). Design for Policy: London: Gower.

Bremner, C., Rodgers, P. (2013). “Design without Discipline.” Design Issues, 29(3), pp. 4-13. https://doi. org/10.1162/desi_a_00217

Brugha, R., Varvasovszky, Z. (2000). "Stakeholder Analysis: A Review.” Health Policy and Planning, 15(3), pp. 239-246. Retrieved from

http://heapol.oxfordjournals.org/content/15/3/239.full.pdf

Burns, C., Cottam, H., Vanstone, C., Winhall, J. (2006). RED PAPER 02: Transformation Design. Retrieved from www.designcouncil.org.uk/ sites/default/files/red-paper-trans formation-design.pdf

Design Commission. (2014a). Design and Public Services: Meeting Needs Saving Money Humanising Services Engaging Citizens. Retrieved from

http://www. policyconnect.org.uk/apdig/sites/site_apdig/files/report/164/field reportdownload/designcommission report-restartingbritain2-designpublic services.pdf

Design Commission. (2014b). Design Research and Public Policy: Current Practice Working to Intersect with Government. Retrieved from http://www.policyconnect.org.uk/apdig/ 
sites/site_apdig/files/report/475/fieldreportdownload/term paperdesignresearchsummer2014.pdf Donmoyer, R. (2000). "Generalizability and the Single-Case Study." In R. Gomm, M. Hammersley, P. Foster (Eds.), Case Study Method: Key Issues, Key Texts (pp. 45-68). Thousand Oaks, CA: Sage. Dykes, T. H., Rodgers, P. A., Smyth, M. (2009). “Towards a New Disciplinary Framework for Contemporary Creative Design Practice.” CoDesign, 5(2), pp. 99-116. Taylor \& Francis Online: https://doi.org/10.1080/15710880902910417

Gronroos, C. (2007). Service Management and Marketing (3rd ed.). New York: Wiley.

Gruhl, D., Bailey, J., Spohrer, J., Maglio, P. (2007). “Steps Toward a Science of Service Systems.” Computer, 40(1), pp. 71-77.

Jones, P. H. (2014). "Systemic Design Principles for Complex Social Systems.” In G. Metcalf(Ed.), Social Systems and Design (Vol. 1, pp.91-128). London: Springer Verlag.

Junginger, S., Sangiorgi, D. (2009). Service Design and Organizational Change: Bridging the Gap Between Rigour and Relevance. Paper presented at the 3rd IASDR Conference on Design Research, Seoul, Korea.

Kimbell, L. (2009). Service-Dominant Logic and Design for Service. Paper presented at the Service Design Network Conference, Madeira, Portugal.

Kimbell, L. (2011). “Designing for Service as One Way of Designing Services.” International Journal of Design, 5(2), pp. 41-52.

Leon, N., Davies, A. (2008). “Managed Service Paradox.” IBM Systems Journal, 47(1), pp. 153-166.

Madano Partnership. (2012). Scoping Study on Service Design. London: Arts and Humanities

Research Council, Design Council, and Economic \& Social Research Councill.

Manzini, E. (2011). “Introduction.” In A. Meroni, D. Sangiorgi (Eds.), Design for Services (pp. 1-5). Surry, UK: Gower.

Manzini, E., Coad, R. (2015). Design When Everybody Designs: An Introduction to Design for Social Innovation. Cambridge, MA: MIT Press.

Manzini, E., Staszowski, E. (Eds.). (2013). Public and Collaborative: Exploring the Intersection of Design, Social Innovation and Public Policy. New York: DESIS Network.

Marshall, J., Bleecker, J. (2010). “Undisciplinarity.” In P. Rodgers, M. Smyth (Eds.), Digital Blur: Creative Practice at the Boundaries of Architecture, Design and Art (pp. 216-223). Faringdon, UK: Libri.

Mulgan, G. (2014). Design in Public and Social Innovation: What Works and What Could Work Better. Retrieved from http://www.nesta.org.uk/sites/default/files/design_in_public_and_ social_innovation.pdf

Mulgan, G. (2014b). Innovation in the Public Sector: How Can Public Organisations Better Create, Improve and Adapt? Retrieved from http://www. nesta.org.uk/sites/default/files/ innovation_in_the_public_sector_how_can_public_organisations_better_create_improve_and_adapt 0 . pdf 
Mulgan, G., Tucker, S., Ali, S., Sanders, B. (2011). Social Innovation: What It Is, Why It Matters and How It Can Be Accelerated. Retrieved from eureka. sbs.ox.ac.uk/761/1/Social_Innovation. pdf Newbery, P., Farnham, K. (2013). Experience Design: A Framework for Integrating Brand, Experience, and Value. Hoboken, NJ: John Wiley \& Sons.

Office for National Statistics. (2016).

UK Index of Services: August 2016. Retrieved from https://www.ons.gov.

uk/economy/economicoutputand productivity/output/bulletins/index ofservices/august2016

Pinheiro, T. (2014). The Service Startup: Design Gets Lean. Kindle Edition, Eise. Prahalad, C. K., Ramaswamy, V. (2004). "Co-Creation Experiences: The Next Practice in Value Creation.” Journal of Interactive Marketing, 18(3), pp. 5-14.

Public and Corporate Economic Consultants. (2015). Research to Assess the Nature and Annual Value of Student Start-Ups. Retrieved from http:// www.hefce.ac.uk/pubs/rereports/year/2015/ssu/

Rodriguez, L., Peralta, C. (2013). From Product to Service Design: A Thinking Paradigm Shift. Paper presented at the RDS2: Emerging Contexts for Systems Perspectives in Design, Oslo, Norway.

Sangiorgi, D. (2008). Service Design as the Design of Activity Systems. Paper presented at the ISDN3, Newcastle.

Sangiorgi, D. (2010). “Transformative Services and Transformation Design.” International Journal of Design, 5(1), pp. 29-40. Retrieved from http:// www.ijdesign.org/ojs/index.php/IJDe sign/article/view/940/344

Sangiorgi, D., Prendiville, A., Jung, J., Yu, E. (2015). Design for Service Innovation \& Development Final Report. Retrieved from

http://imagination.lancs.ac.uk/sites/default/files/outcome_downloads/desid_report_2015_web.pdf

Sangiorgi, D., Prendiville, A., Ricketts, A. (2014). Mapping and Developing Service Design Research in the UK. Retrieved from http://imagination.la ncs.ac.uk/outcomes/Mapping_and_ Developing_Service_Design_Research_UK_\%E2\%80\%93_Final_report_2014

Secomandi, F., Snelders, D. (2011). “The Object of Service Design.” Design Issues, 27(3), pp. 20-34. https://doi. org/10.1162/desi_a_00088

Spohrer, J. C., Maglio, P. P. (2010). “Toward a Science of Service Systems: Value and Symbols.” In P. P. Maglio, C. A. Kieliszewski, J. C. Spohrer (Eds.), Handbook of Service Science (pp. 157-195). New York: Springer

Stickdom, M., Schneider, J., Marc, S. (2014). This Is Service Design Thinking.: Basics, Tools, Cases. Amsterdam: BIS.

Sun, Q. (2011). "Embedding Employability in the Curriculum: A Comparative Study of Employer Engagement Models Adopted by Design Programmes in China and the UK." Journal of Chinese Entrepreneurship, 3(1), 36-48.

Tether, B. S. (2013). “Services, Innovation, and Managing Service Innovation.” In M. Dodgson, D. Gann, N. Phillips (Eds.), The Oxford Handbook of Innovation Management (pp. 600-624). Oxford: Oxford University Press. Trading Economics. (2016). United Kingdom Government Spending to 
GDP. London: Author. Triple Helix Research Group. (2010). The Triple Helix Concept. Retrieved from http://triplehelix.stanford.edu/3helix_concept

Vargo, S. L., Lusch, R. F. (2011). "It's All B2B ... and Beyond: Toward a Systems Perspective of the Market."

Industrial Marketing Management, 40(2), pp. 181-187. Retrieved from

http://www.sciencedirect.com/scie nce/article/pii/S0019850110001082

Yao, K. (2014). "China Services Activity Rebounds but Property Remains a Worry.” Business

News, Reuters, Beijing. Retrieved from http://uk.reuters.com/article/2014/09/03/uk-china-economypmi-id UKKBN0GY02F20140903.

Yin, R. K. (2011). Applications of Case Study Research. Thousand Oaks, CA: Sage. Zomerdijk, L. G., Voss, C. A. (2010).

“Service Design for Experience-Centric Services.” Journal of Service Research, 13(1), pp. 67-82.

\section{Author biographies}

Qian Sun is a senior tutor in service design at the Royal College of Art and (RCA) and is leading the overall strategy of growing research activities in the department. Before joining the RCA in 2013, she was the program leader of MSc. Design

Management at the University of Salford. Her research interests cover service design, design management, and design policy. She publishes regularly on these topics for major journals, books, and conferences; is frequently invited to review papers for conferences, book proposals, and journals; and has been an external examiner for a number of institutions. She currently serves on the Arts and Humanities Research Board Peer Review Panel and is a member of the All-Party Design \& Innovation Group and Design Commission.

Carolyn Runcie is a program manager and tutor in the service design program at the RCA. She has created and developed design courses at the RCA and Imperial College London since 2007, when she coled Design London, the HEFCE- and NESTA-funded joint venture between the two institutions. Before joining the RCA, she worked in the financial services sector and spent time in Italy, where she designed and taught courses in private language schools. She holds a master's in design from Central Saint Martins College of Art \& Design and is a trained teacher (B.Ed Hons). 